\title{
Efek Kertas Warna Kuning Terhadap Memori Eksplisit
}

\author{
Sudrajad Yudo Putra ${ }^{1 *}$, Endah K. Purwaningtyas ${ }^{2}$ \\ 1.2. Fakultas Psikologi, Universitas Islam Negeri Maulana Malik Ibrahim, Malang \\ *E-mail: yudoputras@gmail.com
}

\begin{abstract}
Abstrak
Penggunaan kitab kuning pada pesantren, khususnya di Tambakberas Jombang memberikan keunikan tersendiri dalam hal belajar. Perbedaan lembaga pendidikan yang banyak menggunakan kertas warna putih menjadikan penggunaan kertas warna kuning sesuatu yang unik. Warna kuning memberikan kesan psikis menyenangkan. Kesan ini termasuk dalam emosi yang positif. Emosi yang positif akan mempengaruhi kinerja otak dalam ranah tugas-tugas kognitif seperti memori. Sehingga emosi yang positif akan mempengaruhi memori. Sehingga penggunaan kertas warna kuning akan mempengaruhi memori. Metode penelitiannya menggunakan eksperimen dengan metode pengumpulan berupa soal yang berisi kata-kata. Menggunakan analisis kovarian dengan nilai signifikansi 0,009, dan uji-t dengan nilai signifikansi 0,425 . Hasil analisis ini pengaruh kertas warna kuning terhadap memori eksplisit diterima dengan adanya pre-tes/pengulangan. Kesimpulannya adalah Penggunaan kertas warna kuning dapat mempengaruhi memori eksplisit dengan adanya pre-tes/pengulangan. Sehingga, kegiatan belajar seperti membaca akan lebih berpengaruh menggunakan kertas warna kuning. Alasannya adalah emosi yang ditimbulkan oleh warna kuning memberikan dampak pada tugas-tugas kognitif. Saran dalam penelitian ini adalah pengajar maupun pelajar untuk menggunakan kertas warna kuning dalam mencatat dan membaca ketika belajar.
\end{abstract}

\section{Keywords: Kertas Warna Kuning; Memori Eksplisit}

\section{Mukadimah}

Lembaga pendidikan pondok pesantren merupakan lembaga yang identik dengan kitab kuningnya, karena kertas kitab yang digunakan berwarna kuning kecoklatan. Padahal lembaga pendidikan umum banyak yang menggunakan kertas berwarna putih. Kertas kuning yang khas ini pada pondok pesantren sudah cukup lama digunakan, bahkan pada pondok pesantren Tambakberas Jombang masih menggunakan kertas ini. Dalam Psikologi warna, warna kuning memiliki makna tertentu. Kuning adalah ringan-pemberian (Johannes Itten, 1970: 84-85).

Selanjutnya warna adalah pantulan cahaya dari permukaan berpigmen ditransmisikan ke otak oleh mata. Untuk mengalami warna, cahaya harus hadir untuk memberikan sensasi visual. Warna tidak memberikan sifat fisik seperti sentuhan atau rasa. Sebaliknya, itu adalah psikologis, warna merangsang berbagai tanggapan emosional. Respon emosional bervariasi, tergantung pada masingmasing orang(Universitas Texas A dan M, 2002: 1).

Emosi yang gembira akan mempermudah dalam menyerap informasi untuk diingat seperti apa yang dikatakan oleh Darmansyah dalam Rizkawati Mustian (2015: 2). Sedangkan warna memberikan efek psikis yang bermacam-macam, tergantung warnanya, bahwa warna memiliki peran informasi, peran kebudayaan, dan bahkan peran untuk keberlangsungan hidup (Adhifah Rahayu, 2012). Selanjutnya, ada warna (dalam bentuk cetakan) mempengaruhi proses pembelajaran, termasuk 
membaca(Dr. Oluwakemi O. dan Dr Omoniyi Tayo, 2015).

Proses membaca memiliki keterkaitannya dengan memori, seperti yang dijelaskan oleh Atkinson dan Shiffrin(1968) dalam Jonathan Ling dan Jonathan Catling(2012: 55) yaitu memori dibagi menjadi dua, memori jangka pendek dan memori jangka panjang. Memori jangka pendek memiliki kapasitas 20-30 detik dalam keberadaannya. Sedangkan memori jangka panjang tidak memiliki batasan kapasitas, berlangsung dari menit hingga tak terhingga(Stephen K. Reed, 2011: G-4). Sedangkan jangka panjang memiliki dua aspek, yaitu memori implisit dan memori eksplisit. Memori implisit adalah memori otomatis atau tak sadar dimana pengetahuan sebelumnya membantu kinerja tugas tanpa ada kesadaran. Sedangkan memori eksplisit adalah ingatan sadar tentang informasi. Pada penelitian ini berfokus pada memori eksplisit.

Memori eksplisit merupakan memori yang berasal dari pengalaman-pengalaman sadar. Memori ini memiliki kemampuan untuk mengingat sesuatu dengan dirasakan langsung dalam proses mengingat oleh individu. Stephen K. Reed (2012: 117) mengatakan memori eksplisit adalah memori yang dinilai dengan tes memori langsung. Menurut Edward E. Smith dan Stephen M. Kosslyn (2014: 166) memori eksplisit adalah bentuk memori jangka panjang yang dapat secara sadar dapat dikumpulkan kembali dan "dideklarasikan" atau dijelaskan pada orang lain, misalnya memori pada fakta, ide, dan kejadian. Sedangkan menurut Robert Solso, dkk (2007: 138) memori eksplisit adalah memori yang melibatkan upaya mengingat pengalamanpengalaman sebelumnya secara sadar. Terutama mengandalkan pengambilan (retrieval) pengalaman-pengalaman sadar dan menggunakan isyarat (cue) berupa rekognisi dan tugas-tugas recall (Robert Solso, 2007: 206)..

\section{Metode}

Penelitian ini menggunakan metode eksperimen, yaitu dengan menggunakan desain Solomon (Solomon four group design) dengan randomisasi desain membagi subyek menjadi empat secara random. Kelompok awal dan kedua diberikan uji awal, sedangkan kelompok tiga dan empat tidak adanya uji awal.

Adapun pengumpulan data menggunakan soal yang berisi kata-kata. Diujikan kepada subyek yang berumur 13-15 tahun dengan tingkat IQ rata-rata bawah (100-104) sampai rata-rata atas (105-108). Jumlah laki-laki dan perempuan 20:20. Dibagi menjadi empat kelompok yang sama rata. Dianalisis menggunakan analisis kovarian pada kelompok pertama yang menggunakan kertas kuning dengan kelompok kedua yang menggunakan kertas putih, dan uji-t pada kelompok ketiga yang menggunakan kertas kuning dengan kelompok keempat yang menggunakan kertas merah.

\section{Hasil}

Aadapun hasil analisis yang diperoleh dari analisis analisis kovarian dan uji-t adalah sebagai berikut.

Tabel 1.

Tabel Analisis Kovarian Dependent Variable : PASCA

\begin{tabular}{lcc}
\hline Source & $\mathrm{F}$ & Sig. \\
\hline Corrected Model & 5.233 & .017 \\
\hline Intercept & 12.467 & .003 \\
\hline PRE & 8.672 & .009 \\
\hline Kelompok & .619 & .442 \\
\hline Error & & \\
\hline Total & & \\
\hline Corrected Total
\end{tabular}

\section{Corrected Total}

a R Squared $=.381($ Adjusted $\mathrm{R}$ Square $=.308)$

Berdasarkan hasil analisis statistik di atas adalah nilai signifikansi sebesar 0,009. Sedangakan Ho diterima jika nilai signifikansi $<0,05$, dan $\mathrm{Ho}$ ditolak jika nilai signifikansi $>0,05$. Hasil pada tabel 4.8 adalah signifikansi $0,009<0,05$, maka Ho diterima, artinya terdapat pengaruh kertas warna kuning terhadap memori eksplisit.

Sedangkan hasil dari uji analisis uji-t adalah sebagai berikut: 
Tabel 2.

Hasil Uji-T

\begin{tabular}{|c|l|c|c|c|c|c|}
\hline \multicolumn{7}{|c|}{ Independent Sample Test } \\
\hline \multirow{2}{|c|}{} & \multicolumn{2}{|c|}{$\begin{array}{c}\text { Levene's Test for } \\
\text { Equality of Variance }\end{array}$} & \multicolumn{2}{|c|}{ t-test for Equality of Means } \\
\cline { 3 - 7 } & Fig. & t & df & Sig. (2-tailed) \\
\hline \multirow{2}{*}{ Memori } & Equal Variances assumed & 1.205 & .287 & -.816 & 18 & .425 \\
\cline { 2 - 7 } & Equal Variances not assumed & & $0,301 * * *$ & -.816 & 14.310 & .428 \\
\hline
\end{tabular}

Berdasarkan tabel 4.9, diketahui signifikansi 2tailed 0,425. Sehingga signifikansi 2-tailed 0,425> 0,05 Ho ditolak, artinya tidak terdapat perbedaan antara kertas warna kuning dan kertas warna merah terhadap memori eksplisit.

\section{Diskusi.}

Adapun subyek kelompok eksperimen 1 (Kuning) dan kelompok kontrol 2 (Putih) dihitung memiliki hasil analisis kovarian dengan nilai signifikansi sebesar $0.009<0.05$ dengan Ho diterima artinya terdapat pengaruh warna kertas kuning terhadap memori eksplisit dengan adanya pre-tes atau pengulangan.

Sedangkan pada subyek kelompok eksperimen 3 (Kuning) dan kelompok 4 (Merah) setelah dihitung memiliki hasil analisis uji-t dengan nilai signifikansi sebesar $0.425>0.05$ yang berarti Ho ditolak artinya tidak terdapat perbedaan antara penggunaan kertas berwarna kuning dengan kertas berwarna merah dalam memengaruhi memori eksplisit.

Hasil analisis data kovarian dan analisis data uji-t menunjukkan bahwa tidak adanya pengaruh kertas kuning terhadap memori eksplisit. Akan tetapi, akan memiliki pengaruh jika menggunakan pretes/pengulangan dalam penggunaan kertas warna kuning terhadap memori eksplisit.

Lalu, Lloyd Peterson dan Margaret Peterson (tt) dalam tulisan buletin Psikologi oleh Magda Bhinnety (tt) yang berjudul "Struktur dan Proses Memori" menjelaskan bahwa pengulangan kembali (rehearsal) sangat penting dalam memori jangka pendek untuk masuk ke dalam penyimpanan memori. Hal ini menguatkan penelitian ini, pengulangan yang terjadi pada subyek eksperimen memiliki pengaruh terhadap memori eskplisit yang menimbulkan emosi dari hasil kertas warna kuning.

Selanjutnya, Ashby, Isen dan Turken (1999) menjelaskan mengenai neuropsikologis tentang pengaruh emosi terhadap kognitif. Seseorang yang dalam keadaan emosi netral akan memiliki cukup dopamin. Jika seseorang tersebut dalam keadaan emosi positif maka dopamin akan meningkat dalam sistem mesokortikolimbik. Hal ini akan meningkatkan kinerja berbagai tugas kognitif termasuk memori. Lalu, Bower (1981) mengatakan dengan teori jaringan yang menyatakan bahwa emosi direpresentasikan oleh node atau unsur memori semantik, yang menggambarkan setiap jenis emosi tertentu seperti senang, depresi, atau takut mempunyai sebuah node tertentu atau unit dalam memori yang menyatukan aspek-aspek lain dari emosi tersebut (Martono dan Dicky Hatjarjo, tt: 102).

\section{Kesimpulan.}

Berdasarakan penelitian ini disimpulkan bahwa terdapat pengaruh penggunaan kertas warna kuning terhadap memori eksplisit, jika dilakukan pretes/rehearsal/pengulangan kembali

\section{Saran}

Adapun hasil dari penelitian ini yang menyatakan bahwa penggunaan kertas berwarna kuning terdapat pengaruh terhadap memori eksplisit, maka disarankan kepada pemerintah dan lembaga 
pendidikan dalam kebijakannya untuk menggunakan kertas berwarna kuning dalam media belajar pada proses belajar mengajar. Serta saran kepada peneliti selanjutnya untuk lebih memperhatikan sampel, desain eksperimen, soal kata-kata, dan kualitas kertas yang digunakan.

\section{Referensi}

Bahri, S. (2015). Pembuatan Pulp Dari Batang Pisang. Jurnal Teknologi Kimia Unimal 4:2. Hlm. 36-50. (Online). (diakses pada 20 Januari 2017).

Bassano, M. (2009). Terapi Musik dan Warna. Yogyakarta: Rumpun Buku.

Bhinnety, M. (tt). Struktur dan Proses Memori. Buletin Psikologi. (Online). Nomor 2. Volume 16. Hlm. 7488. ISSN: 0854-7108. (diakses 20 Januari 2017).

Guyton, A.C. \& Hall, J.E. (2014). Buku Ajar Fisiologi Kedokteran. Jakarta: EGC.

Hastjarjo, D. (1994). Pengukuran Ingatan. Buletin Psikologi. (Online). Tahun II. Nomor 2. ISSN: 0854-7106. (diakses pada 20 Januari 2017).

Habsari, S. U. H. (2010). Aplikasi Semiotik \& Efek Psikologi Tampilan Warna Pada Rumah Minimalis. Riptek. (Online). Nomor 1. Volume 4. Hlm. 37-44. (diakses pada 12 Desember 2016).

Itten, J. (1970). The Elements of Color. New York: Van Nostrand Reinhold Company.

Latipun. (2015). Psikologi Eksperimen. Malang: UMM Press.

Ling, J. \& J. Catling. (2012). Psikologi Kognitif. Erlangga.

Lusyana, H. (2008). Formulir Protokol.Universitas Kristen Maranatha.
Mahzumi, F. (2016). Kitab Kuning: Jejak Intelektualisme Pesantren. (Online). (diakses pada 20 Januari 2017).

Martono \& D. Hastjarjo. (tt). Pengaruh Emosi Terhadap Memori. Buletin Psikologi. (Online). Volume 16. Nomor 2. Hlm. 98-102. ISSN: 0854-7108. (diakses pada 20 Januari 2017).

Munsell. (tt). The Munsell Book of Color. (Online). www.munsell.com. (diakses pada 1 Oktober 2016).

Reed, S. K. (2011). Kognisi Teori dan Aplikasi. Jakarta: Salemba Humanika.

Richardson-Klavehn, A. \& R. A. Bjork. (1988). Measures of Memory. University of California. (Online). (diakses pada 1 Oktober 2016).

Setyohadi, R.M. B. (2010). Pengaruh Warna Terhadap Kamar Tidur Anak. Jurnal Teknik Sipil \& Perencanaan. (Online). Nomor 1. Volume 12. Hlm. 79-90. (diakses pada 20 Januari 2017).

Smith, E.E. \& Kosslyn, S.M. (2014). Psikologi Kognitif: Pikiran dan Otak. Yogyakarta: Pustaka Pelajar.

Solso, R. L. (2007). Psikologi Kognitif. Erlangga

Tulving, E. (1972). Organization of Memory.(Online). Library of Congress Catalog Card Number: 73-182647. New York: Academic Press, Inc. (diakses pada 20 Januari 2017).

Wahyuni, N. (2015). Pengaruh PAPARAN Warna Hijau Dan Kuning Terhadap Memori Jangka Pendek Penyandang Tunagrahita Ringan Di SMALB-C Dharma Asih Pontianak. Abstrak. ProNers Jurnal Keperawatan. (Online). http://jurnal.untan.ac.id. (diakses pada 12 Desember 2016).

(2002). The Elements of Color. Texas A\&m University. (Online). (diakses pada 1 Oktober 2016). 